INTERMARUM: history, policy, culture. - Issue 6 .

UDC 94"19":343.1(477.42)

DOI 10.35433/history.11192

Maksymov Oleksandr, $\mathrm{PhD}$ in History, Senior Lecturer at the Department of History of Ukraine, Zhytomyr Ivan Franko State University max-84@ukr.net ORCID: https://orcid.org/0000-0002-5251-3794

ResearcherID: H-5394-2016

Hardzel Kateryna,

Lecturer at Zhytomyr Cooperative College of Business and Law katua.kov@gmail.com

\title{
INFANTICIDE AS A MANIFESTATION OF WOMEN'S DEVIANT BEHAVIOR IN THE RIGHT-BANK UKRAINE IN THE LATE 19th - EARLY 20th CENTURIES (ON THE MATERIALS OF THE ZHYTOMYR COUNTY COURT)
}

\begin{abstract}
This article analyses the subject and the motives of the crime against the life of a newborn baby on the Right-Bank Ukraine in the late 19th-early 20th centuries. The methodology of the infanticide study is based on general scientific principles of historicism, objectivity, consistency, and comprehensiveness. The principle of historicism has been applied to consider infanticide under the historical circumstances of the period and determine the prevalence of this phenomenon in modern Ukrainian society. The principle of objectivity has consisted in the analysis of court cases on infanticide to present reliable facts about this crime. The principle of consistency has aided in establishing the place of female infanticide in deviant behavior manifestations. The principle of comprehensiveness has served for a thorough analysis of the literary and document source base, factual consideration of all storylines of the issue under study. The adopted interdisciplinary approach has enabled to use research tools of other social sciences and humanities. The scientific novelty of the study lies in a comprehensive study of infanticide in the Right-Bank Ukraine
\end{abstract}


IНТЕРМАРУМ: історія, політика, культура. - Вип. 6.

at the end of the 19th - the beginning of the 20th century in terms of the subject and the motives of the crime carried out on the extensive source base.

From the results of the study, the authors conclude that the subjects of infanticide were predominantly unmarried women in difficult living conditions. Children deprived of life were illegitimate. The primary motives behind the crime were hidden in the society's attitude to extramarital affairs and illegitimate children. Violation of unwritten norms caused women's condemnation by the community and close relatives, which resulted in their marginalization. There were passive and active ways of murdering a child. A newborn could die because of a mother's inactivity or active actions aimed to deprive a child of life.

Keywords: infanticide, deviant behavior, Zhytomyr County Court, illegitimate children.

Introduction. Nowadays, cases of infanticide are increasingly reported in the media. Unfortunately, the ratio of female infanticide is increasing. Therefore, this acute social problem attracts the attention of researchers from various fields of knowledge: historians, ethnologists, psychologists, sociologists, doctors, and lawyers. This interest is evoked by both the specific nature of this crime and the component elements of the motivational complex. It is relevant to consider this issue in retrospect, especially during the period of modern society formation. The killing of a newborn child as a manifestation of female deviation deserves further research. This article discloses the main motives of such behavior, its relation to the family status, age and social roles of a woman.

The analysis of this issue in the regional scope is of special interest. The problem of female infanticide on the territory of the Right-Bank Ukraine in the late 19th - early 20th centuries has not been researched before, therefore it is poorly discussed in contemporary Ukrainian historiography. I. Ignatenko's study is noteworthy, the author addresses the problem of infanticide through the prism of premarital relations of the Ukrainian youth and stresses public condemnation of sexual relations before marriage (Ignatenko, 2014, p. 95). The scientific contribution of $\mathrm{O}$. Kis' is also worth mentioning. The researcher is the first in Ukraine to carry out a comprehensive historical and ethnographic study of the status of women in the Ukrainian peasantry and to determine the causes of women's deviant attitude to illegitimate 
INTERMARUM: history, policy, culture. - Issue 6.

children by analyzing the situation of unwed mothers (Kis', 2012, 287 p.). V. Masliychuk is one of the modern Ukrainian researchers who has considered in detail the phenomenon of infanticide. In his study, the researcher considered the problem of illegitimate children murdering and abortion in the period of early modern Ukrainian society in the Left Bank and Sloboda Ukraine (Masliychuk, 2008, 128 p.).

To date, there are no studies on female infanticide on the territory of modern Ukraine, because this topic is considered being uncomfortable and unpleasant, therefore the problem of female infanticide deserves thorough consideration and further investigation.

This research aims to present a comprehensive analysis of female infanticide as a manifestation of women's deviant behavior in the RightBank Ukraine in the late 19th - early 20th centuries.

Findings and discussion. The issues of Ukrainian youth extramarital relationships in the late 19th - early 20th centuries are controversial. Not always the relationship between a woman and a man followed the model ideal in the society of that time. Therefore, often with extramarital pregnancy, women tried to get rid of a fetus or a newborn baby for fear of being condemned by the community. The question of whether infanticide or just murder of a newborn baby was widespread in the specified period remains topical.

Statistical data on the cases of female infanticide in the late 19th early 20th centuries are presented in «The Survey of Volyn Province», where information on the number of violent and accidental deaths in Volyn Province is recorded (Table 1). For comparison, the number of recorded cases of murders of the adult population in Volyn province was determined.

Having analyzed the data from "The Survey of Volyn Province" for the years 1885-1913, we can state that cases of infanticide were frequent. They ranged from $30 \%$ to $80 \%$ of the number of adult murders. It is also characteristic that in the early $19^{\text {th }}$ century the number of adult murders outweighs the cases of baby murders. This can be attributed to the socio-political events that took place in the Russian Empire in the specified period.

Table 1. The number of cases of infant and adult murders in Volyn Province. («The Survey of Volyn Province», 1885, 1886; «The Survey of Volyn Province», 1887, 1888; "The Survey of Volyn 
IНТЕРМАРУМ: історія, політика, культура. - Вип. 6.

Province», 1889, 1900; «The Survey of Volyn Province», 1906, 1907; «The Survey of Volyn Province», 1910, 1911; «The Survey of Volyn Province», 1913, 1914)

\begin{tabular}{|c|c|c|}
\hline Year & Infant Murder & Adult Murder \\
\hline 1885 & 24 & 72 \\
\hline 1887 & 30 & 44 \\
\hline 1899 & 37 & 45 \\
\hline 1906 & 36 & 118 \\
\hline 1910 & 40 & 82 \\
\hline 1913 & 54 & 151 \\
\hline
\end{tabular}

However, these data do not reflect the real numbers of infanticide cases since the case of infanticide did not always become known. A significant number of infant deaths could be classified as accidental. The cases of overlaying, when a woman put a baby near her in bed and accidentally smothered them to death rolling over a baby in sleep, were not infrequent (Bezgin, 2013, p. 198). At present we cannot answer whether overlying was conscious or unintentional. However, it can be assumed that some of these deaths resulted from intentional acts, where the victims were children born out of wedlock.

Infanticide was considered mainly as a "female" crime. Women were responsible for preserving a baby's life, both in the womb and after they were born (Gernet, 1911, p. 101). M. Gernet points out that the number of women accused in this crime in the late 19th - early 20 th centuries was $98 \%$ (Gernet, 1911, p.123).

The analysis of the data shows that offenses against the life and health of individuals occupied a special place in crimes committed by women. In 1885, they accounted for $37 \%$ and in 1899 for $50 \%$ of the total number of female crimes considered by the Zhytomyr County Court. Mostly, women attempted on the lives of the loved ones. These were the murders of husbands; women were led to these crimes by difficulties in getting a divorce or husband's cruelty (Kulikova, 2014, p. 10). However, the highest ratio of murders was cases of murdering newborn babies. That is why infanticide takes the leading place in crimes committed by women. 
INTERMARUM: history, policy, culture. - Issue 6.

Statistics also recorded the number of baby killings in rural and urban areas. The analysis of the data obtained from «The Survey of Volyn Province» confirm that infanticide was more widespread in villages than in towns (Table 2).

Table 2 Number of cases of infanticide in towns and counties of Volyn Province. («The Survey of Volyn Province 1885», 1886; «The Survey of Volyn Province 1887», 1888; «The Survey of Volyn Province 1889», 1900; «The Survey of Volyn Province 1906», 1907; «The Survey of Volyn Province 1910», 1911; «The Survey of Volyn Province 1913», 1914)

\begin{tabular}{|c|c|c|}
\hline Year & In towns & In counties \\
\hline 1885 & 2 & 22 \\
\hline 1887 & 4 & 26 \\
\hline 1899 & 5 & 32 \\
\hline 1906 & 2 & 34 \\
\hline 1910 & 1 & 39 \\
\hline 1913 & 6 & 48 \\
\hline
\end{tabular}

This quantitative discrepancy can be explained by the number of inhabitants in towns and villages. However, V. Bezgin points out that the reason for a bigger number of baby killings in villages is a better possibility to conceal the infant's corpse. Given this, the researcher argues that the statistics of recorded baby killings in urban areas were closer to the truth but significantly lower in the countryside (Bezgin, 2013, p. 200).

M. Gernet states that not only child killings but also other crimes against life prevailed in the countryside. According to the researcher, the total number of murders depended on the level of education of the population. The higher the level of education, the fewer attempts on human life. As the level of illiteracy among the peasants was high, the number of cases of infanticide in the countryside was significant (Gernet, 1911, p.146).

Speaking about the psychological and social portrait of the criminal, or more precisely of the female criminal, the following picture is observed: infanticide was taken as a «female» crime (Kulikova, 2011, p. 101). However, not always a woman herself wanted to deprive her 
IНТЕРМАРУМ: історія, політика, культура. - Вип. 6.

baby of life. She could have done it under the pressure of another person, particularly the man from whom she became pregnant. But even in these cases, the blame would lie with a woman.

In most cases, the accused women were not married, though in judicial practice there were cases when unwanted babies were murdered by women who had been married, for example, widows or divorced. M. Gernet notes that during the period 1897-1906, in the Russian Empire unmarried women constituted $73.6 \%$, married ones made up $16.8 \%$ and widows accounted for $9.6 \%$ of the women charged with abandoning a newborn baby without adequate care and baby killing. These statistics are confirmed by the data obtained from the court cases of the late $19 \mathrm{th}^{\mathrm{h}}$ - early 20th centuries in the Zhytomyr County Court. The following results were collected from 63 court cases: 53 unmarried women, 7 married women, 3 - widows («The Survey of Volyn Province 1899», 1900; «The Survey of Volyn Province 1906», 1907,).

The exceeding number of unmarried women accused of infanticide can be explained by the attitude of society to premarital relations, which were utterly condemned. The fear of public condemnation, neglect, the future ruined life made unmarried girls in pregnancy kill their fetus or newborn baby. In 1894, in the village Chernytsi, Novograd-Volynsky County, in the house where the unmarried Natalia Danylyuk lived, the corpse of a newborn baby was found. A medical examination found the baby was born viable and died as a result of not providing the necessary care. The girl confessed to the crime and explained her crime for the fear of community condemnation in case of disclosing her extramarital affairs (State Archives of Zhytomyr Region - F. 24. Op. 15. D.442. L. 40).

Another group of the infanticide is constituted by the married women, who could murder the babies born out of wedlock, these children were admitted as «fornication». But sometimes they killed legitimate children because of material difficulties, inability to provide their living. But such cases were extremely rare. The overwhelming majority of married women, accused of infanticide, were wives of soldiers. A long separation with a husband destroyed the habitual way of life of a soldier's wife. The fate of a soldier's wife sometimes was worse 
INTERMARUM: history, policy, culture. - Issue 6.

than the fate of a widow, as a lonely future and uncertainty would await her.

With husbands being recruited and absent from home, wives lacked a man's tenderness for a long time. This situation was a cause for women's irregular sexual life (Masliychuk, 2008, p. 37). Therefore, when pregnant, a soldier's wife usually tried to make sure the husband and his family would not know about her misconduct. In 1881, in the village Sapozhin, Ostrog County, the soldier wife Maria Chuyanova was accused of infanticide by her fellow villagers. At first, the woman denied this fact and claimed she was not pregnant (State Archives of Zhytomyr Region - F. 24. Op. 14. D. 168. L. 2). But during the search in her house, the corpse of the baby was found in a chest, and the woman confessed to the crime. The woman explained her action by fear and shame to her husband, who had served for over two years (State Archives of Zhytomyr Region - F. 24. Op. 14. D. 168. L. 22).

Women who lost their husbands - widows - also attempted to conceal the consequences of their infidelity. In 1893, in Stanyshivka village, Zhytomyr County, the villagers found a corpse of a baby near the cemetery. They accused the peasant Barbara Shulska of infanticide, as she had been considered pregnant by the villagers (State Archives of Zhytomyr Region - F.24. Op. 15. D. 420. L. 19). The woman denied it, but after conducting a medical examination, which established that she had been pregnant, Barbara Shulska confessed to what she did. It was also found that the baby was born healthy and died due to a lack of necessary help and care. The woman explained her act by the fear of exposing extramarital relations and condemnation from the villagers (State Archives of Zhytomyr Region - F.24. Op. 15. D. 420. L. 19).

A characteristic trend is observed concerning the age of women accused of infanticide. The majority of the accused were young women aged from 18 up to 25 . The data of the analysed cases in Zhytomyr County Court show that $87 \%$ of the accused were women under 25, and women over 25 made up only $13 \%$.

The young age of the infanticides might be connected with their life ignorance and inexperience that made them a victim of temptation. Young age, alongside with a prevalence of unmarried women among the accused of killing a baby, gives the ground to believe that in most cases they gave birth for the first time. This condition became important in 
IНТЕРМАРУМ: історія, політика, культура. - Вип. 6.

examining the mental state of young women recently confined (Gernet, 1911, p. 154).

It must be noted here that mostly women from poor social classes servants and housemaids - were accused of infanticide. Though the absence of cases of killing a child among women from privileged classes does not indicate they did not commit such crimes.

Wealthy women, predominantly residents of towns, had more opportunities to hide their childbirths. At their disposal, they had special midwives, who assisted in childbirth that should not have become known to the public. They saw the so-called «secret» woman in childbirth at home and took the further settlement of children upon themselves. In one of the examined court cases, the accused was a midwife who, with the consent of the woman in childbirth Elena Yasinsky, killed a newborn baby (State Archives of Zhytomyr Region F.24. Op. 15. D. 422, L. 18 opp.).

In the case of killing newborn babies, wealthy women had more opportunities to successfully conceal the crime. They could also give birth outside of permanent residence (Guernet, 1911, p. 127).

Therefore, mainly the representatives of poor social classes, who worked as servants and maids and were at the edge of a difficult financial situation were in the «lists» of the infanticides. In 1893, the case of an unmarried peasant, Agrippina Gontireva, which was accused of strangling an illegitimate child, was presented to the Zhytomyr County Court. The corpse of an infant wrapped in cloth, mouth stuffed with ground, was found near the road (State Archives of Zhytomyr Region - F. 24. Op. 14. D. 4. L. 3). At first, the woman denied her pregnancy and the fact of childbirth but then confessed. She said she worked in a manor. After the childbirth, she was denied employment. Left without means of support, the woman sought help from her aunt, but she refused. Unsuccessful attempts to find a job drove her into despair. On her way from the village where she tried to find a job again, the woman got off the road and began to strangle a child who was crying too loudly at that moment (State Archives of Zhytomyr Region F.24. Op. 14. D. 4. L. 22).

It should be understood that women who worked as maids could not leave a house for a long time, without arousing suspicion. Driven by fear of losing a job, a woman continued to work until the very beginning 
INTERMARUM: history, policy, culture. - Issue 6.

of childbirth, which could lead to unexpected consequences, including infanticide. In 1891, the cook Stepanida Vavrynovska gave birth to a girl at work. She explained she had not been feeling well since the morning, but did not want to tell anyone about it. When she went down to the cellar, she felt bad and lost her consciousness (gave birth to a baby). After coming into the senses, the woman left the baby and went to the kitchen so that the owners did not notice her absence. Returning later, the cook saw the baby had died. A medical examination established the baby was born viable and died because of blood loss due to a ruptured umbilical cord (State Archives of Zhytomyr Region $-\mathrm{F}$. 24. Op. 14. D. 185. L. 22).

Maids worked 16 or more hours per day. They rarely had time for rest and days off, so it was difficult for them to take care of their children. Besides, the owners with great reluctance hired women with children. That is why, sometimes, pregnant maids tried to get rid of a fetus or a baby.

Having considered the prevalence of such type of crime as murdering a newborn baby (or infanticide) and having identified the family status, age and social status of women, we move to the discussion of the motives of the crime, as they determine the essence of the analyzed offense. The specificity of the motives lies in the fact that in most cases they are related to the so-called "moral values" of society. M. Gernet notes "predominantly women were guilty of infanticide, and this proves the main cause of killing a baby is the society's attitude to children born out of wedlock" (Gernet, 1911, p. 140). The negative attitude of the society towards natural children, and to premarital sexual relations, resulted in attempts to get rid of them.

Children born out of wedlock received the status of «illegitimate» and were condemned by the community. They were called «baistryuk», «kopyl», «bezbatchenko». The position of these children was very difficult. They had no rights and were regularly reminded of their status in society. Such children were deprived of the right to carry the father's family name or claim the inheritance after his death. Even if the parents of such children got married after their birth, they remained illegitimate, carried the "inferiority" mark, and had difficulty in getting married (Pavliuk, 2006, p. 255). 
IНТЕРМАРУМ: історія, політика, культура. - Вип. 6.

Girls who lost their virginity and gave birth to a child without being married (the so-called «pokrytka») were of special status. They belonged to deviant social groups. That is why women who became pregnant out of wedlock preferred to conceal their pregnancy through abortion, or dared to kill a newborn baby.

Having analyzed the cases of Zhytomyr County Court in the late 19th - early 20th centuries, we concluded that the overwhelming majority of the accused women had explained their crime by fear and shame before the community. Women did not want to have their pregnancy become known. In 1896, the villagers of Tulyn, Zhytomyr District, addressed the village headman with the news about the corpse of a newborn child in the river, they suspected it was the peasant Paraskovia Kalylichenko's child (State Archives of Zhytomyr Region F.24. Op.14. D. 781. L. 4). The unmarried woman confessed of having given birth to a child, she said she bore a baby near a mill and threw the infant into the water. A medical examination proved the child was born viable and healthy and died as a result of drowning. The woman explained she had committed the crime «under the influence of fear and shame» (State Archives of Zhytomyr Region - F.24. Op. 14. D. 781. L. 50 opp.).

In the analysis of such a crime, the fact that a difficult financial situation could be one of the motives and sometimes the main factor that made women kill a baby cannot be discounted. Thus, in 1882, in Krasyliv, the owner of the house found in the barn a corpse of a child belonging to her servant, Olympiad Fisher. A medical examination found that a newborn girl died as a result of two stab wounds. The woman confessed she had killed the baby a few days after delivery. She explained that she was out of money and could ask no one for help. At first, the girl wanted to drown herself, but then changed her mind and slaughtered the baby in despair. After that, she returned to Krasyliv, where she worked and hid the corpse of the child (State Archives of Zhytomyr Region - F.24. Op. 14. D. 231. L. 2 opp.).

Often, women were driven by the fear of being left without shelter and the reaction of relatives to the news about extramarital pregnancy. In 1893, Zhytomyr County Court considered the case of an unmarried peasant, Irina Konashukova, who was accused of infanticide. The infant's corpse was found in the house where she 
INTERMARUM: history, policy, culture. - Issue 6.

lived with her father and brothers (State Archives of Zhytomyr Region - F.24. Op. 15. D. 335. L. 50). At first, the woman did not admit her guilt and later confessed that she "got pregnant by the person who refused to marry her", so she concealed the pregnancy. According to Konashukova, she gave birth on the roof of the house. For no one to hear the baby's cry, she tied the baby's neck with a piece of rope from her apron (State Archives of Zhytomyr Region - F. 24. Op. 15. D. 335. L. 50 opp.). The woman claimed that she was afraid of the condemnation, reproach of her father and brothers, and the possibility of «being deprived of shelter» (State Archives of Zhytomyr Region F. 24. Op. 15. D. 335. L. 51).

As we have noted, there were married women among those who committed infanticide. Their main motive was to conceal fornication and its result from the husband. In 1903, in Sapozhyn village, Ostrog County, the soldier's wife Eudokia Gunt was accused of infanticide by the villagers. At first, the woman denied this fact and claimed that she was not pregnant (State Archives of Zhytomyr Region - F. 24. Op. 15. D. 1961. L. 2). But after a search in her house, the child's corpse was found in a chest, and the woman admitted to what she had done. She explained her crime by the fear and shame of her husband, who had been in the service for a long time (State Archives of Zhytomyr Region - F. 24. Op. 15. D. 1961. L. 22).

Some women alleged unconscious state. Both women accused of leaving their child without adequate care and the ones accused of active infanticide pleaded a state of unconsciousness. Such an explanation of the crime might not always be true, but in rare cases the possibility of an unconscious state of the female infanticide could be admitted. In the materials of the Zhytomyr County Court, we found a case where the unconscious state of a woman was recorded by witnesses. In 1905, the inhabitants of the village Yarun, Novograd-Volyn County, found the accused woman in the barn unconscious with a newborn baby who no longer showed signs of life. A medical examination determined that the baby was born viable and died as a result of not providing the required postnatal care. The accused stated that she remembered nothing as she had lost consciousness during childbirth (State Archives of Zhytomyr Region-F. 24. Op. 16. D. 1900. L. 22). 
IНТЕРМАРУМ: історія, політика, культура. - Вип. 6.

The last issue of our study is the ways of infanticide. In the theory of criminal law terms «active» and «passive» infanticide are used. Passive infanticide refers to deliberate leaving a newborn baby without adequate postnatal help and care, which leads to their death. Active infanticide is the use of active actions and means by a mother to kill her child immediately after their birth.

As the practice of the analysed crimes has shown, women mostly left their newborns without proper help and care, causing them to die. It was a passive infanticide. The baby's death could have occurred from asphyxia; the infant was often in an uncomfortable position, facing down. Cases of child death due to hypothermia were reported when children were left in the yard or the premises. In 1893, near the village Hluplyany, Ovruch County, the villagers found a corpse of a newborn boy near the road. A medical examination determined that the baby was born viable but died due to low temperature and lack of necessary assistance (State Archives of Zhytomyr Region - F.24. Op. 15. D. 328, L. 2 opp.). Cases of death related to hypothermia are common as newborns are sensitive to minimal temperature changes. In conditions of secret childbirth in untreated places the risk of infant deaths increased.

There were cases when the child died because of a fall that led to fatal injuries. Women explained that could happen as a result of childbirth in a standing position, in outhouses, when overcoming fences or descending from an attic (Lindenberg, 1910, p. 15). In 1893, in the village Lyubarska Guta, Novograd-Volynsky County, a corpse of a child was found in the vegetable garden that belonged to the father of the accused Isabella Cheretskaya. The woman confessed that the baby had died as a result of the stroke as she gave birth while standing. A medical examination confirmed that the death of a child was due to hemorrhage caused by a stroke (State Archives of Zhytomyr Region F.24 Op. 15. D. 330. L. 3).

In reference to the active ways of infanticide, the most common was suffocation, which could be carried out by various means. Predominantly suffocation was done with the help of hands. Various items, such as grass, ground, bread crumbs, or a piece of cloth, were also used. In 1892, in the village Stara Chortoria, Novograd-Volynsky County, a corpse of an infant was found in the vegetable garden. 
INTERMARUM: history, policy, culture. - Issue 6.

Medical examination established that death was caused by suffocation (State Archives of Zhytomyr Region - F. 24. Op. 15. D. 35. L. 3).

Along with suffocation, which was quite common, there were cases of children's strangulation. As a rule, strangulation was done with tape. Moreover, women could use pieces torn from clothes: shawls, aprons, sweatshirts, skirt laces, etc. In 1893, a baby corpse was found in Novograd-Volynsky County. A medical examination determined that the death of the child occurred due to strangulation. The woman confessed to having done so with a piece of cloth from her apron (State Archives of Zhytomyr Region - F. 24. Op. 15. D. 335. L. 2). In one of the court cases analyzed, the child was strangulated by wrapping an umbilical cord around the neck. In 1887, in Bondarivka, Zhytomyr County, a body of a dead infant was found, buried in a storehouse. A medical examination proved that the baby was born alive and died as a result of strangulation of the umbilical cord, wrapped twice around the neck. The woman wanted to conceal the crime by burning a corpse, as evidenced by the traces of burns (State Archives of Zhytomyr Region F.24. Op. 14. D. 502. L. 3 opp.).

The cases of killing a child by damaging the head with hard objects were less common. It was difficult to determine how the injuries were inflicted and the instrument used. Only when a woman confessed, it became known. As a rule, a medical examination showed numerous injuries of a baby's skull, its fragmentation, which indicated the use of considerable force. In 1881, in the village Rudnya Ozerianska a dead body of a child was found in the storeroom of the soldier's wife Maria Chuyanova. A medical examination determined that the death of the child came as a result of a blow to the head, causing the skull to be broken into two parts (State Archives of Zhytomyr Region - F.24. Op. 14. D. 168. L. 49 opp.).

The alternative ways of killing a baby included stabbing a child, usually with a knife. For example, in 1882, in Krasyliv, Starokostiantynivska County, a corpse of a child was found in the storehouse of the house owner. There were two sharp force injuries on the body, inflicted with a knife. There were also cases of drowning children in rivers, ponds, etc. Sometimes women could tie stones or other objects for the baby not to be found later. In 1880, in Urlya village, Novograd-Volynsky County, a corpse of a child with a stone 
IНТЕРМАРУМ: історія, політика, культура. - Вип. 6.

tied to the neck was found. Medical examination established that the baby was born alive and died as a result of drowning (State Archives of Zhytomyr Region - F.24. Op. 14. D. 100. L. 70 opp.).

Conclusions. From the research that has been carried out it is possible to conclude that the cases of infanticide on the Right Bank Ukraine in the late 19th - early 20th centuries were not uncommon. The deprivation of a newborn child of life during the specified period was «female» in terms of the subject and predominantly "rural" regarding the place where the crime was committed. A generalized portrait of female infanticide in the late 19th - early 20th century includes the following characteristics: a young woman aged 18 to 25 , inexperienced, not married, with significant material difficulties, which led to the inability to maintain a newborn baby. The causes of infanticide are directly related to the attitude of modern society to extramarital affairs and illegitimate children. Women, as a rule, committed this crime for fear of being condemned by the relatives and fellow villagers for their «sinful» actions. Ways of killing a child can be divided into passive and active, a newborn could die both from inactivity of the mother (leaving the child in unsuitable places, not providing the adequate help and care, etc.), and from active actions aimed at depriving the child of life (suffocation, strangulation, drowning, etc.). The scene of the child's murder often became the place of the crime concealment. The study of only one issue - infanticide, opens new vistas for further research into deviant and delinquent behavior of women in modern society.

The study of the issue of infanticide opens new vistas for further research into deviant and delinquent behavior of women in modern society.

\section{BIBLIOGRAPHY}

Bezgin, V. (2013). Infanticide and criminal abortion in rural Russia: past and present. NB: Law and Policy Issues, 4, 196-229. [In Russian].

Gernet M. (1911). Infanticide: Sociological and Comparative-Legal Case Study: with 12 Diagrams Attached Moskva, 346. [In Russian].

Ihnatenko I. (2014). Female body in traditional Ukrainian culture Kyiv: Intelektualna knyha, 264. [In Ukrainian]. 
INTERMARUM: history, policy, culture. - Issue 6.

Kis O. (2012). Woman in Traditional Ukrainian Culture (the second half of the 19th - the beginning of the 20th century) Lviv: Institute of Ethnology National Academy of Sciences Ukraine, 287. [In Ukrainian].

Kulikova S. (2011). Female crime as a social factor in Russian modernization (the second half of the $19^{\text {th }}$ - the beginning of the $20^{\text {th }}$ centuries), Gagarin: Polimir, 174. [In Russian].

Kulikova S. (2014). Female crime in Russia in the second half of the 19th - early 20th centuries: a look from the right. Vesnik of the Moscow University of the Ministry of Internal Affairs of Russia, 10, 915. [In Russian].

Lindenberg V. (1910). Materials on the issue of infanticide and fruitful exile in the Vitebsk province, Yurev: Tip. K. Matissena, 86. [In Russian].

Masliichuk V. (2008). Infanticide in the Left Bank and Sloboda Ukraine in the second half of the 18th century, Kharkiv: Kharkiv private museum of city estate, 128. [In Ukrainian].

Pavliuk S. (red.). (2006). Ukrainian Ethnology, Kyiv: Znannia, 568. [In Ukrainian].

State Archives of Zhytomyr Region. F. 24. Op. 14. D. 100. 941.

State Archives of Zhytomyr Region. F. 24. Op. 14. D. 168. 681.

State Archives of Zhytomyr Region. F. 24. Op. 14. D. 185. 1021.

State Archives of Zhytomyr Region. F. 24. Op. 14. D. 231.1031.

State Archives of Zhytomyr Region. F. 24. Op. 14. D. 4. 901.

State Archives of Zhytomyr Region. F. 24. Op. 14. D. 502.831.

State Archives of Zhytomyr Region. F. 24. Op. 14. D. 781. 901.

State Archives of Zhytomyr Region. F. 24. Op. 15. D. 1961. 571.

State Archives of Zhytomyr Region. F. 24. Op. 15. D. 328. 631.

State Archives of Zhytomyr Region. F. 24. Op. 15. D. 330.731.

State Archives of Zhytomyr Region. F. 24. Op. 15. D. 335. 781.

State Archives of Zhytomyr Region. F. 24. Op. 15. D. 35.681.

State Archives of Zhytomyr Region. F. 24. Op. 15. D. 420. 661.

State Archives of Zhytomyr Region. F. 24. Op. 15. D. 422.971.

State Archives of Zhytomyr Region. F. 24. Op. 15. D. 442.781.

State Archives of Zhytomyr Region. F. 24. Op. 16. D. 1900. 801.

The Survey of Volyn Province 1885 (1886). Zhytomyr: Volyn provincial typography, 83 . 
IНТЕРМАРУМ: історія, політика, культура. - Вип. 6.

The Survey of Volyn Province 1887 (1888). Zhytomyr: Volyn provincial typography, 120.

The Survey of Volyn Province 1899 (1900) Zhytomyr: Volyn provincial typography, 72 .

The Survey of Volyn Province 1906 (1907) Zhytomyr: Volyn provincial typography, 90 .

The Survey of Volyn Province 1910 (1911) Zhytomyr: Volyn provincial typography, 82 .

The Survey of Volyn Province 1913 (1914) Zhytomyr: Volyn provincial typography, 85 .

\section{Максимов Олександр, Гардзель Катерина. ВБИВСТВО ДИТИНИ ЯК ПРОЯВ ДЕВІАНТНӦ̈ ПОВЕДІНКИ ЖІНОК ПРАВОБЕРЕЖНОЇ УКРАЇНИ В КІНЦІ ХІХ -ПОЧАТКУ ХХ СТОЛІТТЯ (НА МАТЕРІАЛАХ ЖИТОМИРСЬКОГО ОКРУЖНОГО СУДУ)}

\section{Анотація}

Метою статті є комплексний аналіз суб'єкта та мотивів злочину проти життя новонародженої дитини на Правобережній Украйні в кінці XIX - на початку XX cm. Методологія наукового вивчення явищ дітозгубництва трунтується на основі таких загальнонаукових принцииів як історизму, об'єктивності, системності, всебічності. Застосування принциипу історизму дало можливість розглянути дітозгубництво відповідно до конкретно-історичних обставин періоду та дозволило простежити динаміку поширення иьього явища в модерному украӥнському суспільстві. Принцип об'єктивності також полягав у залученні судових справ щзодо випадків дітозгубництва з метою представлення лише реальних фактів щодо цьього явища. Принцип системності сприяв виявленню місия дітозгубництва в проявах девіантної поведінки жінок. Принцип всебічності проявився при комплексному аналізі літературноджерельної бази, фактичному врахуванні усіх можливих сюжетних ліній окресленої проблематики. Застосування міждисииплінарного підходу дозволило залучити науковий інструментарій інших суспільногуманітарних наук. Наукова новизна дослідження полягає в тому, що на основі широкої джерельної бази було розглянуто явище дітозгубництва на Правобережній Украйні в кінщі XIX - на початку XX cm., крізь призму суб'єкта та мотивів вчинення даного злочину. У результаті проведених досліджень, автори приходять до таких висновків: існували пасивні та активні способи вбивства дітей. Новонароджений міг померти як від 


\section{INTERMARUM: history, policy, culture. - Issue 6. ISSN 2518-7694 (Print) ISSN 2518-7708 (Online)}

бездіяльності матері так і від активних дій, спрямованих на позбавлення життя дитини. Суб' 'ктом злочину, в переважній більшості, були жінки незаміжні, шьо перебували в складному матеріальному становищі, та, як правило, належали до нижчих сочіальних прошарків. Основні мотиви такого злочину були приховані у ставленні модерного суспільства до позашлюбних стосунків та незаконнонароджених дітей, які автоматично потрапляли в категорію маргіналів. Подібна доля очікувала $\check{u} \ddot{x}$ матерів, порушення неписаних норм якими тягнуло за собою осуд громадою та близькими родичами.

Висвітлення лише одного аспекту - дітозгубництва дає перспективи для подальших досліджень девіантної та делінквентної поведінки жінок в умовах модерного суспільства.

Ключові слова: дітозгубництво, девіантна поведінка, Житомирський окружний суд, незаконнонароджені діти.

\section{Aleksandr Maksymow, Katarzyna Hardzel. ZABÓJCIE DZIECKA JAKO PRZEJAW DEWIACYJNEGO ZACHOWANIA KOBIET PRAWOBRZEŻNEJ UKRAINY W KOŃCU XIX - NA POCZATKU XX WIEKU (NA PODSTAWIE MATERIALÓW ZYYTOMERSKIEGO SADU OKREGGOWEGO)}

\section{Streszczenie}

Celem artykułu jest wszechstronna analiza osób $i$ motywów przestępstwa przeciwko życiu noworodka na Prawobrzeżnej Ukrainie na przełomie XIX i XX wieku. Metodologia naukowego badania zjawisk zniszczenia dziecka opiera się na takich ogólnych zasadach naukowych jak historyzm, obiektywizm, systematyczność, kompleksowość. Zastosowanie zasady historyzmu umożliwito obejrzeć utratę dziecka zgodnie ze specyficznymi warunkami historycznymi tego okresu i pozwoliło prześledzić dynamike rozprzestrzeniania tego zjawiska we współczesnym społeczeństwie ukraińskim. Zasada obiektywności obejmowała również przyciagnięcie spraw sadowych o przypadkach utraty dziecka $w$ celu przedstawienia tylko prawdziwych faktów tego zjawiska. Zasada systematyczności pomogła zidentyfikować miejsce utraty dziecka $w$ przejawach dewiacyjnego zachowania kobiet. Zasada kompleksowości przejawiała się w kompleksowej analizie literacko-źródłowej bazy, faktycznej analizie wszystkich możliwych linii tematycznych przedstawionych problemów. Zastosowanie podejścia interdyscyplinarnego pozwoliło wykorzystać narzędzia naukowe innych nauk społecznych i humanistycznych. Oryginalnościq naukowa badania jest to, że w oparciu o szeroka bazę źródłowa zbadano zjawisko utraty dziecka na Prawobrzeżnej Ukrainie na przełomie XIX $i$ XX wieków poprzez pryzmat 
IНТЕРМАРУМ: історія, політика, культура. - Вип. 6. ISSN 2518-7694 (Print) ISSN 2518-7708 (Online)

osoby i motywy przestepstwa. W wyniku badań autorzy stwierdzili, że istniaty pasywne i aktywne sposoby morderstwa dzieci. Noworodek mógt umrzeć zarówno z powodu bezczynności matki, jak $i$ z aktywnych działań, mających $w$ celu pozbawienie życia dziecka. Przedmiotem przestępstwa byly w większości niezamężne kobiety, które znajdowaty się $w$ trudnej sytuacji finansowej $i$ zwykle należaty do niższych klas społecznych. Główne motywy tego przestępstwa byly ukryte $w$ stosunku wspótczesnego społeczeństwa wobec spraw pozamatżeńskich i nieślubnych dzieci, które automatycznie zaliczaty się do ludzi zmarginalizowanych. Podobny los czekat także na ich matki, bo naruszenie niepisanych zasad spowodowało osądy ze strony społeczności $i$ bliskich krewnych.

Oświetlenie tylko jednego aspektu - utraty dziecka, daje perspektywy do dalszych badań nad dewiacyjnym i przestepczym zachowaniem kobiet we wspótczesnym społeczeństwie.

Stowa kluczowe: utrata dziecka, zachowanie dewiacyjne, Żytomierski sąd okręgowy, dzieci nieślubne.

The article was received 08.27.2019 Article recommended for publishing 09.21.2019 